\title{
Seleksi Mutan Generasi Dua (M2) Kedelai Hitam Terhadap Produksi Tinggi
}

\section{Selection of Black Soybean Mutant Second Generation (M2) For High Production}

\author{
Siti Novridha Andini ${ }^{1}$, Jaenudin Kartahadimaja ${ }^{1}$, dan Miranda Ferwita Sari ${ }^{1}$ \\ ${ }^{1}$ Politeknik Negeri Lampung \\ *E-mail : sitinovridaandini@polinela.ac.id
}

\begin{abstract}
The number of black soybean varieties in Indonesia is less than the yellow one. Black soybeans contain anthocyanin which is good for health. Black soybean is also the raw material of soy sauce and other food processing. The genetic diversity of black soybean varieties needs to be increased to improve the genetic using plant breeding. The mutation is a method of plant breeding to produce a new variety. This research aims to get the high production genotypes and the observational variables that are used for M3 selection. This research used a non-factorial randomized block design. The treatments were $0 \mathrm{~Gy}, 50 \mathrm{~Gy}, 100 \mathrm{~Gy}, 150 \mathrm{~Gy}, 200 \mathrm{~Gy}$ that repeated three times, so was obtain 15 experimental units, with each experimental unit contains 6 rows and consist of 4 plants. The seven observation variables that consist of plant height; the number of branches, flowering age, number of pods, harvesting age, the weight of 100 grains, and the weight of seeds per plant were analyzed for the diversity using NTSYS software, and the coefficient of genotype diversity was calculated. The genotypes that had high production at the 50 Gy dose were 1 (11), 4 (25), 6 (25), and 2 (26); for the 100 Gy dose were 1 (14), 6 (25), 1 (11), 4 (1); for the 150 Gy dose were 3 (19), 5 (10), and 6 (1); and for the dose 200 Gy were 1 (19) and 1 (26), and the observational variables that are selected for M3 selection were the number of branches, number of pods, and seed weight per plant.
\end{abstract}

Keyword: black soybean, mutation, selection

Disubmit : 5 Maret 2021; Diterima: 27 Maret 2021; Disetujui : 19 April 2021

\section{PENDAHULUAN}

Indonesia masih sangat sedikit melepas varietas kedelai hitam dibandingkan kedelai kuning. Nurrahman (2015) menyatakan komposisi kimia antara Mallika (Kedelai hitam), Grobogan dan Kedelai Impor hanya Kedelai hitam Mallika yang terdapat antosianin, sedangkan kedelai kuning tidak terdeteksi. Kedelai hitam tergolong bahan pangan fungsional, hubungan Kedelai hitam dengan kesehatan menjadi isu yang menarik dikarenakan memiliki komponen isoflavon yang terdapat di kotiledon biji kedelai dan antosianin terdapat di kulit kedelai. Menurut (Ginting E., dkk. 2015), varietas unggul berkontribusi dalam meningkatkan produksi kedelai hitam seiring dengan meningkatnya permintaan terhadap bahan baku kecap. Mutiara 2 dan Mutiara 3 merupakan varietas unggul terbaru yang dilepas oleh BATAN. 
Kedelai berkulit biji hitam (kedelai hitam) di Indonesia peruntukan utama digunakan untuk bahan baku kecap. Kedelai hitam telah digunakan untuk beragam olahan pangan; seperti burger, es krim dan sebagainya dibeberapa Negara seperti China, Taiwan, dan Jepang. kedelai hitam yang digunakan sebagai bahan baku kecap tidak hanya meningkatkan kualitas warna kecap menjadi coklat hitam, juga meningkatkan nilai gizi terutama protein. Senyawa antioksidan yang terdapat di kedelai hitam berfungsi sebagai agen antitumor dan senyawa pencegah penyakit kardiovaskular. Senyawa antioksidan yang teridentifikasi adalah flavonol, isoflavon, anthosianin, proanthosianidin, tokoferol, dan asam polikarbosilik. (Balitkabi 2013). Untuk memperkuat penyediaan kedelai hitam, pada tahun 2008, Badan Litbang Pertanian melepas varietas Detam 1 dan Detam 2 (Kementrian Pertanian Badan Litbang Pertanian 2012). Pada Tahun 2013 dilepas varietas Detam 3 dan Detam 4 (Balitkabi 2013). Detam 4 Prida merupakan kedelai hitam yang memiliki potensi hasil 2,5 T/Ha, serta memiliki karakter agak tahan terhadap hama penghisap polong dan agak tahan terhadap penyakit karat daun, namun potensi hasil Detam 4 Prida belum setinggi potensi hasil Detam 3 Prida, sehingga pada penelitian ini diharapkan ditemukannya genotip-genotip yang dapat memiliki potensi hasil tinggi.

Perluasan keragaman genetik varietas kedelai hitam perlu dilakukan untuk perbaikan genetik melalui pemuliaan tanaman. Mutasi merupakan metode pemuliaan tanaman untuk menghasilkan varietas baru. Menurut (Mudibu et al., 2012), pemuliaan mutasi pada tanaman merupakan alat yang efektif di tangan pemulia tanaman terutama pada tanaman yang memiliki basis genetik sempit seperti kedelai. Pada penelitian ini dilakukan seleksi M2 pada setiap dosis iradiasi. Penelitian ini bertujuan untuk mendapatkan genotipgenotip yang memiliki produksi tinggi, dan mengetahui variabel pengamatan yang digunakan untuk seleksi M3.

\section{METODE PENELITIAN}

Penelitian dilaksanakan pada bulan Juni 2020 - Oktober 2020 di lahan penelitian Politeknik Negeri Lampung. Bahan-bahan yang dibutuhkan dalam penelitian ini adalah sebagai berikut: Benih kedelai hitam Mutan generasi dua $\left(\mathrm{M}_{2}\right)$ varietas Detam 4 Prida, dolomit, pupuk kandang, KCl, SP36, Urea, kertas label, kertas amplop, insektisida dan fungisida. Penelitian ini menggunakan Rancangan Acak Kelompok (RAK) non faktorial dengan 3 ulangan. Tiap mutan dua (M2) ditanam sesuai dengan dosis radiasi yaitu R1 (50 Gy), R2 (100 Gy), R3 (150 Gy), dan R4 (200 Gy), dan terdapat kontrol tanpa radiasi yaitu R0 (0 Gy) sehingga didapatkan 15 satuan unit percobaan. Pada setiap unit percobaan ditanam 24 tanaman, satu unit percobaan terdiri dari 6 baris, setiap baris berisi 4 tanaman. Setiap baris dipilih 1 tanaman dengan produksi tertinggi. Pengamatan dilakukan terhadap tinggi tanaman, jumlah cabang, umur berbunga, jumlah polong, umur panen, bobot 100 butir, dan bobot biji pertanaman. Pengamatan tingkat kekerabatan antar tanaman terpilih dilihat dari hasil dendogram dengan program NTSYS Spc 2.02 (Numerical Taxonomy and Multivariate Analysys Systems) .

Rumus perhitungan koefisien keragaman genotipe (KKG) dan koefisien keragaman fenotipe (KKF) menurut Handayani \& Hidayat (2012) yaitu:

$$
\begin{aligned}
& K K G=\frac{\sqrt{\sigma^{2}} G}{X} \times 100 \% \\
& K K F=\frac{\sqrt{\sigma^{2}} F}{X} \times 100 \%
\end{aligned}
$$

Keterangan:

$\sigma^{2} \mathrm{G}=$ akar kuadrat varian genotipe

$\sigma^{2} \mathrm{~F}=$ akar kuadrat varian fenotipe

$\mathrm{X}=$ nilai contoh suatu sifat 
Koefisien keragaman genetik dan fenotip dibagi dalam tiga kategori yaitu : Besar (KKG/KKF $\geq 14,5 \%$ ), sedang $(5 \% \leq \mathrm{KKG} / \mathrm{KKF} 14,5 \%)$ dan Kecil (KKG/KKF < 5\%) (Miligan et al., 1996 cit Halide et al., 2020).

\section{HASIL DAN PEMBAHASAN}

Pengamatan pada masing-masing variabel menunjukkan nilai kisaran populasi (Tabel 1). Setiap variabel pengamatan memiliki kisaran yang lebar dimana ada yang memiliki nilai kurang dari rerata kontrol (R0) dan ada yang memiliki nilai lebih tinggi daripada kontrol. Pada variabel tinggi tanaman, jumlah cabang, jumlah polong, bobot 100 butir dan bobot biji pertanaman ada yang memiliki nilai lebih tinggi daripada kontrol yang kemudian bisa dipilih sebagai genotipe unggul yang bisa dilanjutkan untuk seleksi pada generasi selanjutnya sebagai mutan-mutan yang berpotensi memiliki produktivitas tinggi, sedangkan pada variabel umur berbunga dan umur panen terdapat genotipe tanaman yang memiliki umur lebih cepat daripada tanaman kontrol. Genotipe tanaman tersebut dapat dipilih untuk diseleksi di generasi selanjutnya sebagai calon mutan unggul untuk umur genjah. Selanjutnya pemilihan dilihat berdasarkan dendogram kekerabatan untuk lebih spesifik pada setiap genotipe tanaman di masing-masing perlakuan radiasi.

Tabel 1. Nilai tengah dan nilai kisaran pada variabel pengamatan

\begin{tabular}{lccc}
\hline \multicolumn{1}{c}{ Variabel Pengamatan } & Rerata \pm SD & kisaran populasi tanaman & Rerata Ro \\
\hline Tinggi tanaman & $51.8 \pm 6.76$ & $31-68$ & 50 \\
Jumlah cabang & $5.08 \pm 1.14$ & $3-7$ & 5 \\
Umur berbunga & $35.57 \pm 1.88$ & $31-44$ & 35 \\
Jumlah polong & $227.85 \pm 50.33$ & $125-421$ & 233 \\
Umur panen & $84.77 \pm 1.38$ & $82-91$ & 85 \\
Bobot 100 butir & $13.53 \pm 1.24$ & $11.40-17.92$ & 13.07 \\
Bobot biji/tanaman & $71.97 \pm 18.70$ & $38.57-152.63$ & 80.15 \\
\hline
\end{tabular}

Standar deviasi dan kisaran nilai dihitung untuk mengetahui penyebaran nilai pada setiap variabel pengamatan. Karakter yang memiliki keragaman yang tinggi ditunjukkan dengan nilai standar deviasi yang tinggi dan kisaran nilai karakter yang lebar (Singh \& Chaudhary 1979).

Bobot biji pertanaman pada Tabel 1 memiliki kisaran populasi 38.57 - 152.63, dan rerata R0 80.15, hal ini menunjukkan bahwa terdapat tanaman dengan perlakuan radiasi yang memiliki bobot biji pertanaman yang lebih tinggi dari kontrol. Rashwan \& Abdel (2016) "Seleksi Pedigree pada Kacang ercis (Pisum sativum L.)" mengungkapkan bahwa seleksi Pedigree dari tiga keluarga, di bawah kriteria seleksi yang sama dari hasil polong hijau pertanaman no 1,5 dan 10 yang dievaluasi dalam investigasi adalah galur yang menjanjikan karena hasil biji lebih tinggi pada pertanaman dibandingkan dengan famili lainnya.

Tinggi tanaman berdasarkan kisaran populasi pada Tabel 1, juga tedapat genotipe tanaman yang lebih dari kontrol. Sibarani dkk., (2015) menunjukkan bahwa respon morfologi tanaman kedelai anjasmoro yaitu tinggi tanaman, memilki perbedaan antara kontrol dengan dosis radiasi $300 \mathrm{~Gy}$. Pada hasil penelitian seleksi Mutan generasi ke dua $\left(\mathrm{M}_{2}\right)$ kedelai kipas putih terhadap produksi dan kualitas benih yang tinggi, pada variabel tinggi tanaman tidak berpengaruh nyata. Rata-rata tinggi tanaman memiliki kecenderungan nilai lebih rendah dibandingkan dengan genotipe G15 (kontrol), diduga adanya pengaruh dari efek radiasi yang masih diturunkan ke tanaman generasi M2, sehingga genotipe yang dicobakan memiliki rata-rata tinggi tanaman lebih rendah dibandingkan kontrol (G15) (Dalfiansyah dkk., 2016). Meliala dkk., (2016) menyatakan bahwa tanaman padi gogo, seiring dengan peningkatan dosis radiasi sinar gamma maka tinggi tanaman juga meningkat.

Berdasarkan dendogram yang terbentuk pada radiasi 50 Gy (R1), 18 M2 yang diamati memiliki koefisien kemiripan $1-0$ (gambar 1), dendogram yang terbentuk pada radiasi 100 Gy (R2) memiliki 
koefisien kemiripan $1-0$ (gambar 2), dendogram yang terbentuk pada radiasi 150 Gy (R3) memiliki koefisien kemiripan $1-0.14$ (gambar 3), dan dendogram yang terbentuk pada radiasi 200 Gy (R4) memiliki koefisien kemiripan $0.86-0$ (gambar 4).

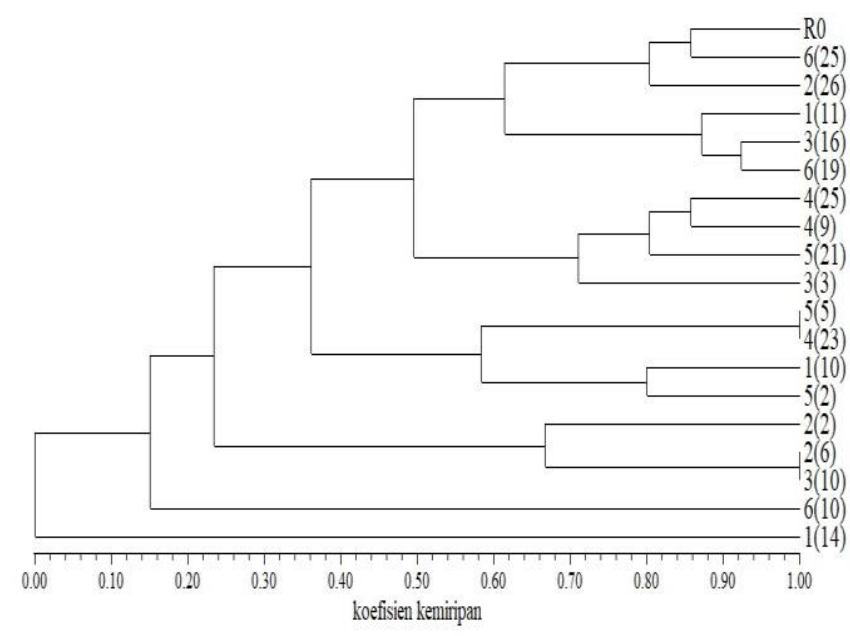

Gambar 1. Dendogram kekerabatan radiasi 50 Gy (R1)

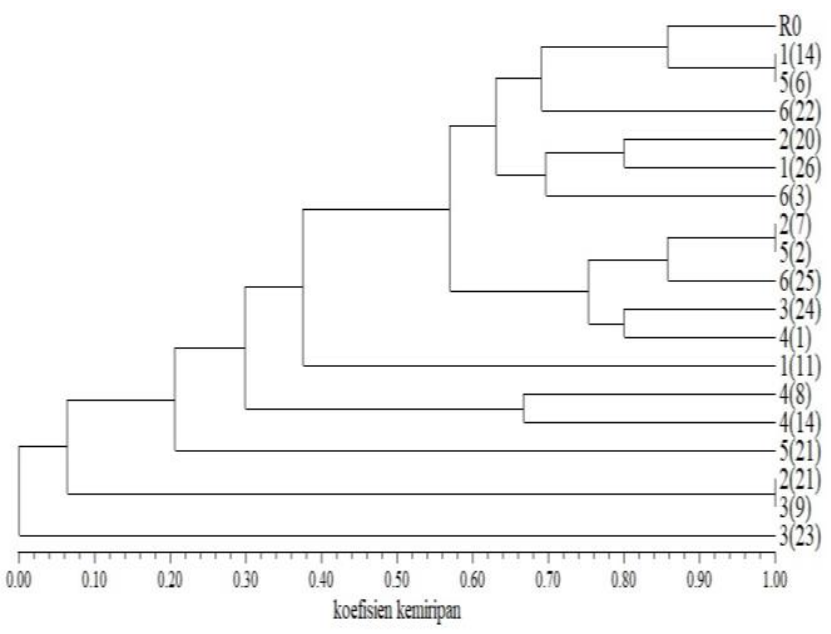

Gambar 2. Dendogram kekerabatan radiasi 100 Gy (R2)

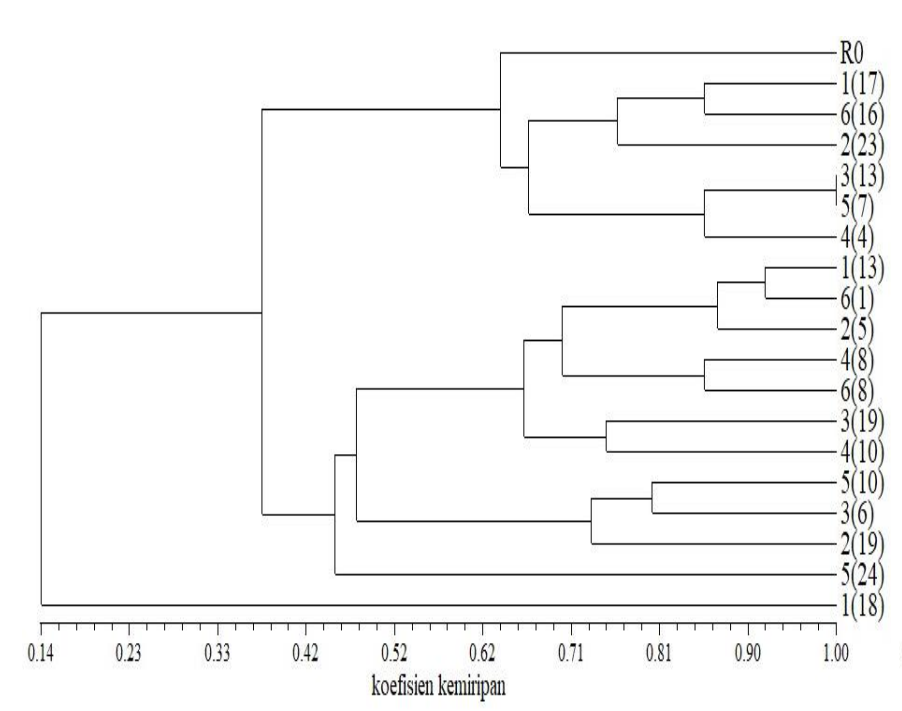

Gambar 3. Dendogram kekerabatan radiasi 150 Gy (R3)

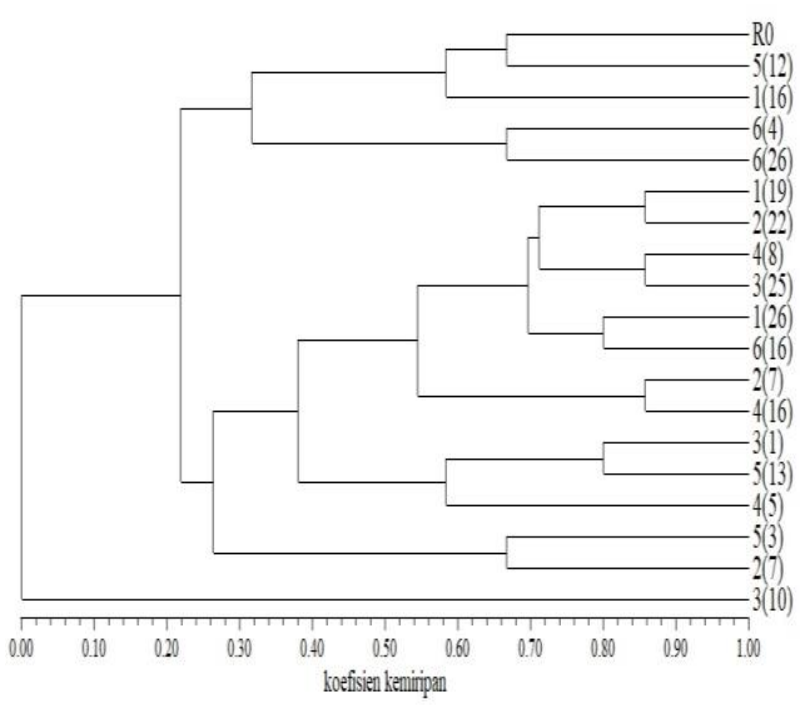

Gambar 4. Dendogram kekerabatan radiasi 200 Gy (R4)

Semua dendogram membentuk 2 kelompok besar yang satu kelompoknya terdiri dari genotipe yang memiliki kekerabatan paling jauh. genotipe yang memiliki koefisien kemiripan paling jauh pada 50 Gy (R1) adalah 1(14) (gambar 1), genotipe 3(23) pada 100 Gy (R2), genotipe 1(18) pada 150 Gy (R3) dan genotipe 3(10) pada 200 Gy (R4). Genotipe-genotipe tersebut memiliki kekerabatan paling jauh dari genotipe lainnya dan tanaman kontrol (tanpa radiasi). Selain itu terdapat beberapa genotipe yang memiliki kekerabatan paling erat dengan nilai koefisien 1 yaitu pada radiasi 50, 100 dan 150 Gy. Genotipe 5(5) dengan 4(23) dan 2(6) dengan 3(10) (gambar 1), 2(7) dengan 5(2) dan 2(21) dengan 3(9) (gambar 2) dan 3(13) dengan 5(7) (gambar $3)$. 
Dasar pertimbangan dalam menyusun strategi konservasi, pemuliaan, pengelolaan dan pemanfaatan sumberdaya genetik tanaman secara berkelanjutan, harus mengetahui informasi baik tingkat individu, spesies, maupun populasi terkait keragaman genetik. Penanda morfologi, biokimia dan DNA dapat menjadi penilaian untuk keragaman genetik tanman (Zulfahmi 2013). Pada penelitian ini analisis kekerabatan dilakukan dengan menggunakan penanda morfologi yaitu karakter-karakter yang berpengaruh terhadap produktivitas. Analisis kekerabatan dilakukan di setiap perlakuan radiasi yaitu 50, 100, 150 dan 200 Gy. Hasil pengamatan 7 karakter morfologi kemudian digunakan untuk mengetahui dendogram kekerabatan pada masing-masing perlakuan radiasi. Miswarti dkk (2017) menyatakan, analisis kekerabatan dapat menggunakan karakter morfologi kualitatif dan kuantitatif, kemudian data tersebut dapat diubah menjadi data biner dalam bentuk skoring data berdasarkan kriteria yang sudah ditetapkan pada tiap peubah.

Keragaman genetik adalah hal penting dalam pemuliaan tanaman dimana keberhasilan program pemuliaan tanaman bergantung dari nilai keragaman genetik. Keragaman genetik yang semakin besar akan memberikan peluang keberhasilan program pemuliaan tanaman yang semakin besar. Selain itu keragaman genetik yang tinggi juga dapat meningkatkan respon seleksi dikarenakan keragaman genetik berbanding lurus dengan respon seleksi (Fehr 1987). Variabel pengamatan sebanyak 7 (tujuh) dalam penelitian ini dengan menggunakan kriteria Miligan et al. (1996) didapatkan bahwa koefisien keragaman genetik kedelai M2 berkriteria kecil dan sedang (Tabel 2).

Tabel 2. Nilai koefisien keragaman genotipe dan koefisien keragaman fenotipe pada setiap variabel pengamatan

\begin{tabular}{lcccc}
\hline \multicolumn{1}{c}{ Variabel Pengamatan } & KKG $(\boldsymbol{\%})$ & Kriteria & KKF $(\%)$ & Kriteria \\
\hline Tinggi tanaman & 4.55 & Kecil & 14.25 & Sedang \\
Jumlah cabang & 10.32 & Sedang & 25.83 & Besar \\
Umur berbunga & 3.68 & Kecil & 6.31 & Sedang \\
Jumlah polong & 11.57 & Sedang & 25.22 & Besar \\
Umur panen & 1.13 & Kecil & 1.83 & Kecil \\
Bobot 100 butir & 4.76 & Kecil & 9.78 & Sedang \\
Bobot biji per tanaman & 8.74 & Sedang & 27.88 & Besar \\
\hline
\end{tabular}

Kriteria keragaman genetik sedang ada pada variabel jumlah cabang, jumlah polong dan bobot biji per tanaman, sedangkan variabel pengamatan tinggi tanaman, umur berbunga, umur panen dan bobot 100 butir memiliki kriteria kecil (Tabel 2). Nilai koefisien keragaman genetik yang kecil menunjukkan bahwa pengaruh lingkungan lebih besar pada variabel tersebut dan nilai koefisien keragaman genetik sedang menunjukkan bahwa pengaruh genetik dan lingkungan sama-sama mempengaruhi variabel tersebut (Jalata, et al. 2011). Nilai koefisien keragaman genetik pada variabel umur panen hampir sama dengan dengan nilai koefisien keragaman fenotipiknya. Trusntinah dan Iswanto (2012) menyatakan, nilai KKG dan KKF yang hampir berdekatan pada suatu karakter menunjukkan bahwa keragaman suatu karakter tersebut lebih disebabkan oleh faktor genetik. 

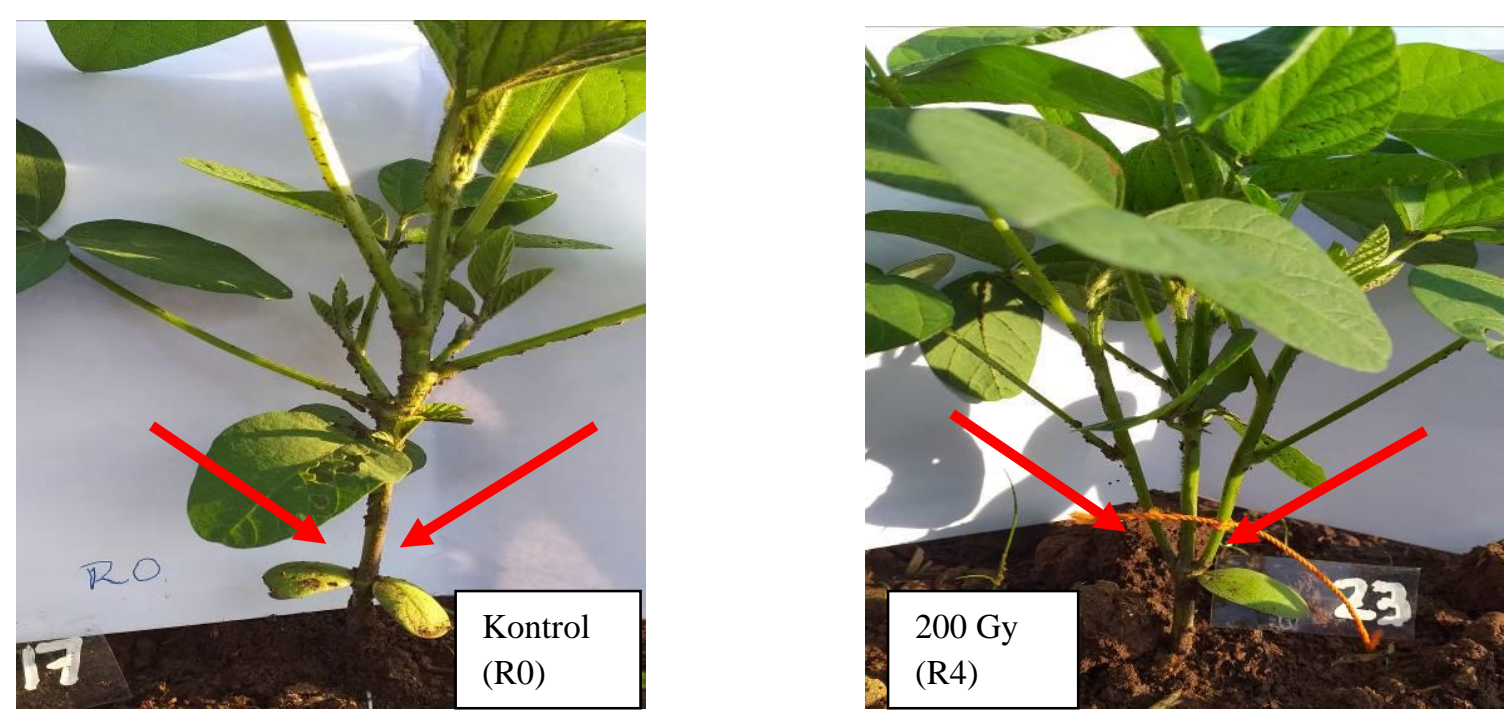

Gambar 1. Pertumbuhan Cabang pada Tanaman Kontrol/R0 (Kiri) dan Tanaman 200 Gy /R4 (Kanan)

Gambar 1 menunjukkan adanya 1 (satu) tanaman di 200 Gy (R4) yang memiliki pertumbuhan cabang yang berbeda antara Kontrol (R0), hal tersebut diduga dikarenakan pengaruh dari radiasi. Perlakuan R0 tidak ada pertumbuhan cabang didekat kotiledon, sedangkan pada 200 Gy (R4) terbentuk cabang didekat kotiledon. Piri et al. (2011) menyatakan perubahan morfologi, struktural dan / atau fungsional yang dimediasi radiasi pada tanaman diatur oleh intensitas dan durasi radiasi gamma.
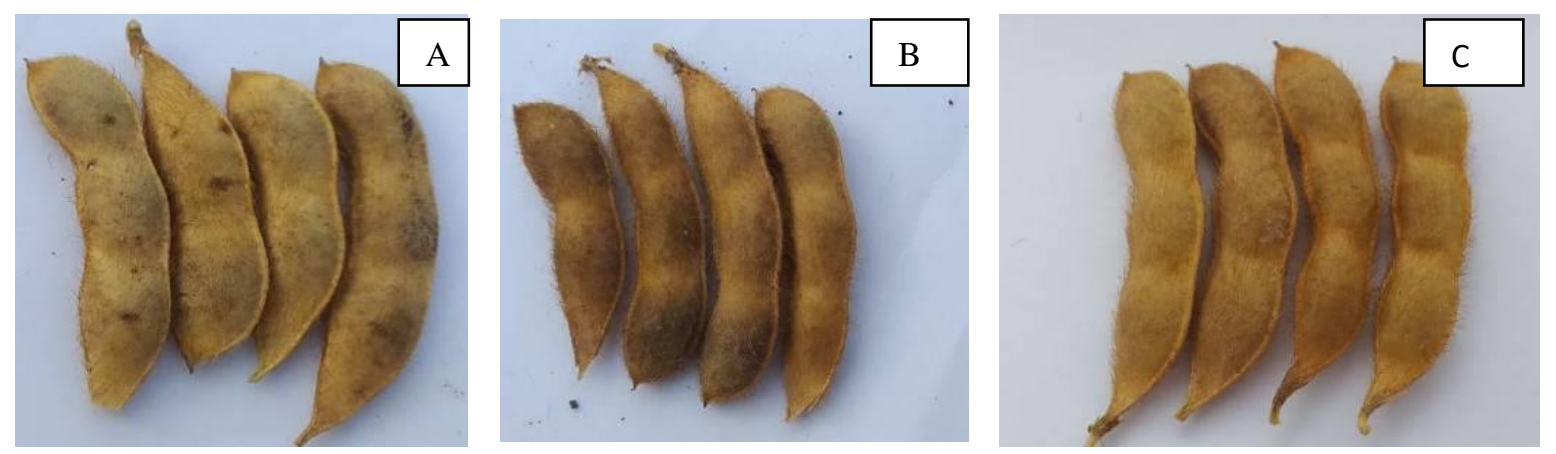

\section{Gambar 2. Warna Polong}

Keterangan: A: 100 Gy(R2), B: Kontrol (R0), C: 200 Gy (R4)

Berdasarkan karakter morfologi tanaman kedelai yang diamati, terdapat beberapa karakter yang berbeda yaitu bentuk cabang, dan warna polong dengan tanaman kontrol. Pada Gambar 2, warna polong pada kontrol berwarna coklat tua, sedangkan pada dosis 100 Gy (R2, genotipe 2) dan 200 Gy (R4, genotip 23) berwarna coklat muda (Gambar 2). Acquaah (2012) menyatakan bahwa mutasi pada umumnya adalah kejadian acak tidak dapat diprediksi, tidak dapat diarahkan secara spesifik gen. Mutasi juga dapat diklasifikasikan menurut jenis perubahan struktural yang dihasilkan sebagai: (1) Variasi ploidi: melibatkan perubahan kromosom nomor (butir atau kehilangan dalam set lengkap kromosom atau bagian dari satu set). (2) Variasi struktur kromosom: melibatkan perubahan struktur kromosom (misalnya, duplikasi segmen, translokasi segmen). (3) Mutasi gen: perubahan konstitusi nukleotida DNA (dengan penghapusan atau substitusi). Menurut Asadi, 2013, mutasi adalah perubahan yang terjadi secara tiba-tiba dan acak pada materi genetik (genom, kromosom, gen). Malek et. al (2014) menyatakan mutan dapat dijadikan bahan pemuliaan dalam perubahan genetik pada beberapa karater tanaman kedelai. 


\section{KESIMPULAN}

Genotip-genotip yang memiliki produksi tinggi pada dosis 50 Gy adalah 1(11), 4 (25), 6 (25), dan 2 (26). Dosis 100 Gy adalah 1(14), 6(25), 1 (11), 4 (1). Dosis 150 Gy adalah 3 (19), 5 (10), dan 6 (1). Dosis 200 Gy adalah 1(19) dan 1 (26), dan variabel pengamatan yang dipilih untuk seleksi M3 adalah jumlah cabang, jumlah polong, dan bobot biji per tanaman.

\section{UCAPAN TERIMA KASIH}

Terimakasih Penulis ucapkan kepada Politeknik Negeri Lampung yang telah memberikan kesempatan memperoleh hibah penelitian DIPA tahun 2020 Nomor: 193.77/PL15.8/PT/2020, serta kepada semua pihak yang telah membantu terselesaikannya penelitian ini.

\section{DAFTAR PUSTAKA}

Acquaah, G. 2012. Principles of Plant Genetics and Breeding. Australia: Blackwell Publishing.

Asadi. 2013. Pemuliaan Mutasi untuk perbaikan terhadap Umur dan Produktivitas pada Kedelai. Jurnal Agrobiogen, 9(3), pp.135-142.

Balitkabi. 2013. Detam 3 dan Detam 4 prida: kedelai Hitam Berumur Genjah. http://balitkabi.litbang.pertanian.go.id/infotek/detam-3-prida-dan-detam-4-prida-kedelai-hitamberumur-genjah/. [14 Maret 2021]..

Dalfiansyah, Zusyana, S. H. 2016. Seleksi Mutan Generasi Ke Dua (M2) Kedelai Kipas Putih Terhadap Produksi dan Kualitas Biji yang Tinggi. Jurnal Agrista, 20(3), pp.115-125.

Fehr, W. R. 1987. Principles of cultivar development. Theory and technique. Vol 1. New York. MacMillan Publishing Co.

Ginting, E., Rahmi , Y., Hari, I.M., dan T. 2015. Varietas Unggul Kedelai Hitam Sebagai Bahan Baku Kecap. Prosiding Seminar Agroindu Stri Dan Lokakarya Nasional 2-3 September 2015, 86-92. Jakarta: FKPT-TPI.

Halide, E. S. dan A. P. Paserang. 2020. Keragaman genetik, heritabilitas dan korelasi antar kentang (Solanum tuberosum 1.) yang dibudidayakan di napu. Biocelebes 14 (1), pp.94- 104.

Handayani, T, \& Hidayat, I. M. 2012. Keragaman genetik dan heritabilitas beberapa karakter utama pada kedelai sayur dan implikasinya untuk selesi perbaikan produksi. J. Hort. 22(4), pp.327-333.

Jalata, Z, Ayana, A \& Zeleke, H. 2011. Variability, heritability, and genetic advance for some yield and yield realated traits in Ethiopian Barley (Hordeum vulgare L.) landraces and crosses. Int. J. Plant Breeding and Genet, 5(1), pp.44-52.

Kementerian Pertanian Badan Litbang Pertanian. 2012. Kedelai Hitam: Bahan Baku Industri. http://www.litbang.pertanian.go.id/info-aktual/1175/. [14 Maret 2021].

Malek, M.A., Mohd Y.R., Most, S. S.A., Ujal, K.N., dan M. Monjurul, A, M. 2014. Morphological characterization and assessment of Genetic variability, character association, and divergence in soybean mutants. The ScientificWorld Journal. Available https://doi.org/10.1155/2014/968796. 1-12.

Meliala, J.H.S., Nur, B., Andi, S. 2016. Radiasi Sinar Gamma Terhadap Perubahan Fenotipik Tanaman Padi Gogo (Oriza sativa L.). Jurnal Prodiksi Tanaman, 4(7), pp.585-594.

Miligan, S.B.K.A., Grovis and F.A. Martine. 1996. Inheritance of sugarcane ratooning ability and the relationship of younger crop traits to older. Crop Sci.

Hal 38 Volume 21, Nomor 1, Tahun 2021 
Miswarti., W.E. Putra., dan D. Sugandi. 2017. Analisiss Keragaman Plasma Nutfah Durian di Provinsi Bengkulu Berdasarkan Karakter morfologi. Bul. Plasma Nutfah, 23 (1), p.59-68.

Mudibu, J., K.K.C. Nkongolo, A. Kalonji-Mbuyi, and V. K. R. 2012. Effect of gamma irradiation on morpho agronomic characteristics of soybean soybean (Glycine max L.). American Journal of Plant Sciences, 3(3), pp.331-337.

Nurrahman. 2015. Evaluasi kompoisisi zat gizi dan senyawa antioksidan kedelai hitam dan kedelai kuning. Jurnal Aplikasi Teknologi Pangan, 4(3), pp. 89-93.

Piri, I., Mehdi, B., Abolfazzl, T., Mehdi, J. 2011. The use of gamma irradiation in agriculture. African Journal Pf Microbiology Research, 5(32), pp.5806-5811.

Rashwan, A.M.A., and Abdel, H. E. 2016. Pedigree Selection in Pea (Pisum Sativum L.). International Journal of Advanced Research, 4(7), pp.1366-1371.

Sibarani, I.B., Lahay, R.R., Hanafiah, D. 2015. Respon Morphologi Tanaman Kedelai (Glycine max (L.) Merril) Varietas Anjasmoro terhadap beberapa Radiasi Sinar. Jurnal Agroekoteknologi, 3 (2), pp.515526

Singh, R.K., B.D. Chaudhary. 1979. Biometrical Methods in Quantitative Genetic Analysis. Kalyani Publ. New Delhi, India.

Sneath, P.H. and R.R. Sokal. 1973. Numerical Taxonomy. W.H. Freeman and company. San Fransisco.

Trustinah, dan R. Iswanto. 2012. Keragaman Bahan Genetik Galur Kacang Hijau. Prosiding Seminar Hasil Penelitian Tanaman Aneka Kacang dan Umbi, pp.465-472.

Zulfahmi. 2013. Penanda DNA untuk analisis genetik tanaman. Jurnal Agroteknologi 3(2), pp.41-52. 